\title{
Abundance of Antarctic picophytoplankton and their response to light and nutrient manipulation
}

\author{
Nona S. R. Agawin*, Susana Agustí, Carlos M. Duarte \\ IMEDEA (CSIC-UIB), Instituto Mediterráneo de Estudios Avanzados C/ Miquel Marqués 21, 07190 Esporles, Mallorca, Spain
}

\begin{abstract}
The response of Antarctic picophytoplankton to experimental light and nutrient manipulation was tested in a large-scale mesocosm experiment in an iron-rich coastal location in the Bransfield Strait (Johnson Cove) during the austral summer of 2000. The experiment consisted of 8 mesocosm units $\left(25 \mathrm{~m}^{3}\right)$, shaded with screens to provide a light gradient (target irradiance $100,50,25$ and $10 \%$ of the ambient light field). A set of 4 mesocosms encompassing the different light treatments was initially run with the ambient nutrient concentrations and in the remaining 4 mesocosms, ammonium $\left(\mathrm{NH}_{4} \mathrm{Cl}\right)$ was added together with phosphate $\left(\mathrm{KH}_{2} \mathrm{PO}_{4}\right)$ and silicate $\left(\mathrm{Na}_{2} \mathrm{SiF}_{6}\right)$ for the first $11 \mathrm{~d}$ of the experiment (Phase I). A second manipulation of light and nutrient (Phase II) was done to confirm the results obtained on Day 16 of the experiment, when the mesocosms shaded to $25 \%$ of the ambient light were exposed to full ambient light, and ammonium, was added to both of the mesocosms already receiving $100 \%$ ambient light. The importance of light availability was evident in the increased abundance of picophytoplankton with increased irradiance, the response being non linear, with the abundance at full ambient irradiance being comparable, or lower, than that at $50 \%$ of the ambient irradiance. There was, in addition, an interaction between light availability and nutrient supply as evidenced by the increased picophytoplankton abundance during the early part of the experiment, with increased nutrient availability in mesocosms exposed to 50 and $100 \%$ ambient light, and not in those shaded to 10 and $25 \%$ ambient light. The response of photosynthesis to irradiance ( $P$ - $I$ curves) showed a strong response to nutrient additions, with extremely high specific photosynthesis rates in the mesocosm with increased nutrient availability and exposed to full ambient light. The response was close to the theoretical maximum possible and provides ample evidence that nutrient additions, particularly ammonium, contribute to the optimum photosynthesis by picophytoplankton in the iron-rich Antarctic coastal waters studied here.
\end{abstract}

KEY WORDS: Picophytoplankton $\cdot$ Antarctica $\cdot$ Light $\cdot$ Nutrient $\cdot$ Mesocosms

\section{INTRODUCTION}

The importance of the smaller-sized phytoplankton (nano- and picophytoplankton) to the Antarctic phytoplankton community is increasingly recognized (Weber \& El-Sayed 1987, Hewes et al. 1990), although it varies across regions and seasons (Mengesha et al. 1998). In a station off the Kerguelen Islands, the

${ }^{*}$ Present address: Ocean Sciences Centre, Memorial University of Newfoundland, St. John's, A1C 5S7 Newfoundland, Canada.E-mail: nagawin@mun.ca microplankton size fraction was the dominant component of the phytoplankton community during summer blooms $(60 \%$ of total integrated biomass), while the nano- and pico-size fractions were the more dominant components during winter (contributed $80 \%$ of total chlorophyll a [chl a] biomass with dominance of the picoplankton size fraction, Fiala et al. 1998). In the vicinity of the Drake Passage/Bransfield Strait, picoplankton accounted for 5 to $74 \%$ of phytoplankton biomass. These studies reported Antarctic picophytoplankton $(<2 \mu \mathrm{m})$ to be dominated by flagellates, typically prasinophytes and prymnesiophytes. 
Although the picophytoplankton fraction may be an important contributor to Antarctic phytoplankton biomass, the factors that control its biomass and production are poorly known. Picophytoplankton maintains low production in Antarctic waters (El-Sayed 1984) despite experiencing high nutrient ( $\mathrm{N}$ and $\mathrm{P}$ ) concentrations. There are several hypotheses to account for this paradox, namely limitation by macro- and micronutrients (e.g. iron), light, high consumer pressure (e.g. Holm-Hansen et al. 1984, Minas \& Minas 1992, de Baar et al. 1995) or low temperature constraints to potential growth rates (e.g. Sommer 1989). Picophytoplankton have a high affinity for nutrients (Donald et al. 1997) and are unlikely to be nutrientlimited in nutrient-rich Antarctic waters. Although picophytoplankton have developed an adaptive strategy to utilize low irradiance (Morris \& Glover 1981), they may be light-limited in Antarctic waters, particularly in turbid coastal waters and deeply mixed oceanic waters (Sakshaug \& Holm-Hansen 1986, Mitchell \& Holm-Hansen 1991).

Here we test the response of coastal Antarctic picophytoplankton abundance and primary production to experimental shading and nutrient additions in large mesocosms, and examine grazing rates to test their importance in controlling picoplankton production. The experimental test was conducted in a coastal location in the Bransfield Strait, where we also assessed the abundance and primary production of picoplankton.

\section{MATERIALS AND METHODS}

The experiment was conducted from January 24 to February 17, 2000, in Johnson Cove $\left(62^{\circ} 39.576^{\prime} \mathrm{S}\right.$, $\left.60^{\circ} 22.408^{\prime} \mathrm{W}\right)$, a sheltered bay receiving glacial melt, adjacent to the Spanish Antarctic Base (Livingston Island, Shetland Islands, Antarctica, Fig. 1). This sheltered bay receives iron-rich inputs from adjacent glaciers containing iron-rich volcanic ash deposited in past eruptions at nearby Deception Island. The experiment consisted of 8 mesocosm units (14 m in height, $5.3 \mathrm{~m}^{2}$ cross-sectional area, with an effective volume of $25 \mathrm{~m}^{3}$ ), suspended at a depth of $21 \mathrm{~m}$ from a floating platform (Fig. 1). The mesocosms, built with UVstabilized polyethene bags, were filled with ambient unscreened water (from a depth range of 0.5 to $3 \mathrm{~m}$ ) by gravity followed by the use of a water pump. The flexible walls of the mesocosms allowed for turbulent propagation, resulting in thorough mixing of the contents within a few minutes, as revealed by dye experiments in a pilot experiment and by nutrient homogenization for 20 min from the additions. The mesocosms were covered along their sides and top with neutral density shading screens to provide a light gradient (target irradiance 100, 50, 25 and $10 \%$ of the ambient light field). The mean natural surface $(-0.5 \mathrm{~m})$ irradiance in the mesocosms receiving $100 \%$ ambient light during the experimental period was $127 \pm 19 \mu \mathrm{mol} \mathrm{m}{ }^{-2}$ $\mathrm{s}^{-1}$. A set of 4 mesocosms encompassing the different light treatments was initially run with the ambient

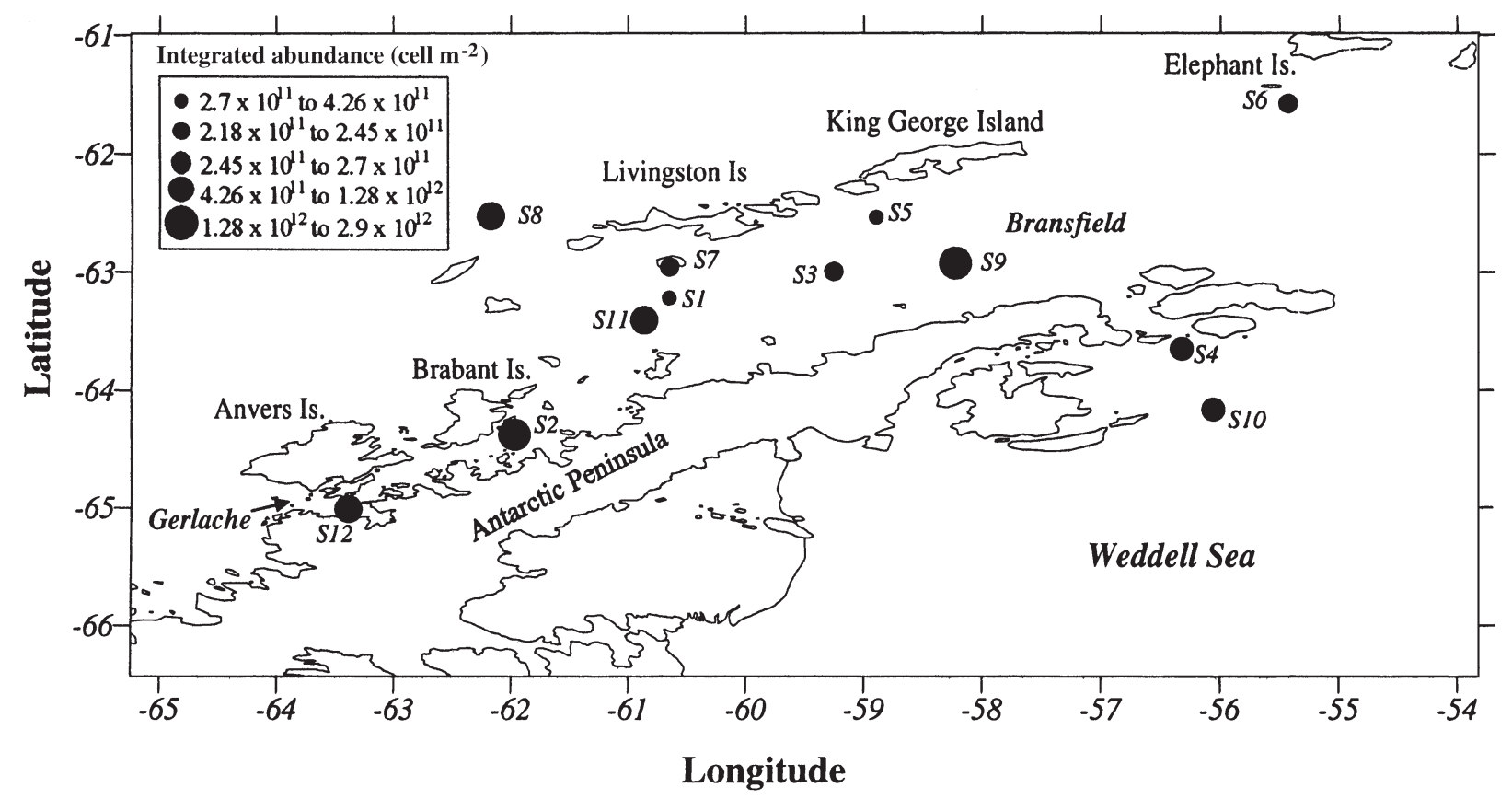

Fig. 1. Map showing the study locations (S1 to S12) in South Shetland Islands, Antarctica. Filled circles denote integrated picophytoplankton abundance 
nutrient concentrations and in the remaining 4 mesocosms, ammonium $\left(\mathrm{NH}_{4} \mathrm{Cl}\right)$ was added as an alternative nitrogen source to nitrate, together with phosphate $\left(\mathrm{KH}_{2} \mathrm{PO}_{4}\right)$ and silicate $\left(\mathrm{Na}_{2} \mathrm{SiF}_{6}\right)$ additions. Nitrogen, phosphorus and silicon were added at a constant ratio (10 N:1 Si:10 P) every day for the first $11 \mathrm{~d}$ of the experiment in mesocosms receiving nutrient amendment and the additions were discontinued afterwards. The nutrient-amended mesocosms received a daily addition of $0.1 \mathrm{~mol} \mathrm{~N}$ (as $\mathrm{NH}_{4} \mathrm{Cl}$ ), $0.1 \mathrm{~mol} \mathrm{Si}$ (as $\mathrm{Na}_{2} \mathrm{SiF}_{6}$ ), and $0.01 \mathrm{~mol} \mathrm{P}\left(\right.$ as $\mathrm{KH}_{2} \mathrm{PO}_{4}$ ). Ammonia was the only inorganic nutrient in short supply because concentrations were low $(<1 \mu \mathrm{M})$ compared to high nitrate concentrations $(30 \mu \mathrm{M})$ in Antarctic waters (Agustí \& Duarte 2000). Light extinction coefficients at Day 11 of the experiment (when nutrient amendment was stopped) were lowest in mesocosms receiving $10 \%$ ambient light, with $\left(-0.36 \mathrm{~m}^{-1}\right)$ and without $\left(-0.41 \mathrm{~m}^{-1}\right)$ nutrient amendment, and highest in mesocosms receiving nutrient amendment at $50 \%$ $\left(-0.57 \mathrm{~m}^{-1}\right)$ and $100 \%\left(-0.56 \mathrm{~m}^{-1}\right)$ ambient light (Phase I). To confirm the results obtained during the first phase of the experiment, a second manipulation of light and nutrient conditions in the mesocosms was done on Day 16 of the experiment (Phase II). The screens shading the mesocosms to $25 \%$ of the ambient light (with and without nutrient amendment) were removed to expose the mesocosms to full ambient light, and ammonium was added to both of the mesocosms already receiving $100 \%$ ambient light. Integrated ( 0 to $12 \mathrm{~m}$ ) water samples of $50 \mathrm{l}$ were collected on alternate days for biological analyses and daily for chemical (dissolved nutrient concentrations) analyses. Dissolved inorganic phosphate and nitrate+nitrite were analyzed following standard methods (Hansen \& Koroleff 1999), and ammonium concentrations were measured spectrofluorometrically (Kéruel \& Aminot 1997). Particulate matter sedimentation losses were also determined during the experiment. Sediment traps consisting of arrays of 4 tubes $(100 \mathrm{ml}$ cylindrical glass centrifuge tubes, $25 \mathrm{~mm}$ diameter), mounted on an array suspended at $5 \mathrm{~m}$ depth into the mesocosms, were deployed for $24 \mathrm{~h}$. every third day. The tubes were closed and mixed before collecting the particles trapped onto a pre-weighed whatman GF/F filter. Two filters were used for determination of chl a concentrations as described below, and the other two were used to calculate the total particulate flux, by weighing the filters after dessication at $60^{\circ} \mathrm{C}$ for $24 \mathrm{~h}$.

Twelve stations, encompassing the broadest possible range of conditions in the Bransfield area (Fig. 1) were sampled aboard RV 'Hesperidés' to assess the abundance and vertical distribution of picophytoplankton in the area. Seawater samples were collected in Niskin bottles on a Rosette system fitted with a CTD at an average of 10 depths from the surface down to $200 \mathrm{~m}$. The abundance of picophytoplankton at each depth and each station was determined on board as described below. A water volume $(200 \mathrm{ml})$ was filtered through Whatman GF/F filters for fluorometric analysis of total chlorophyll concentrations in the water (Parsons et al. 1984). The filters were homogenized and kept refrigerated in the dark while pigments were extracted in $90 \%$ acetone for ca. $6 \mathrm{~h}$. Following extraction, fluorescence was measured in a Turner Designs fluorometer calibrated with pure chl a (Sigma). The light extinction coefficient at the stations sampled was estimated from the attenuation of photosynthetically active irradiance (PAR) with depth, measured at each station from the surface to $100-150 \mathrm{~m}$ by using a $4 \pi$ underwater quantum sensor (LI-192SA, Li-Cor) attached to a SATLANTIC-OCP 100 automatic profiler. The depth of the upper mixed layer (UPML), an index of the stability of surface water column, was calculated as the shallowest depth at which $\sigma_{\mathrm{t}}$ (water density) differs from surface values $\geq 0.05 \mathrm{~kg} \mathrm{~m}^{-3}$ (Mitchell \& Holm-Hansen 1991). Ammonium concentrations (Kennedy unpubl. results) were measured using a spectrofluorometric method, as described in Agustí \& Duarte (2000).

Abundance of picophytoplankton. The abundance and cell size of picophytoplankton were determined every other day in each mesocosm unit by flow cytometric analysis (using red fluorescence and side scatter characteristics of the cells) of duplicate fresh unfractionated samples with a FACSCALIBUR (BectonDickinson) flow cytometer on board. Cell size was calculated from the FSC (forward scatter) data of the picophytoplankton cells, calibrated using fluorescent beads of various sizes (Fluospheres Size Kit \# 2, Molecular Probes) and algal cultures of known sizes, determined through epifluorescent microscope measurements (Chlorella sp., $2.7 \mu \mathrm{m}$; Dunaliella sp., $3.8 \mu \mathrm{m})$. Picoplankton chlorophyll and carbon biomass were calculated by converting picoplankton biovolume measurements to chlorophyll using the value $3645 \mathrm{~g} \mathrm{chl} \mathrm{m}^{-3}$ cell volume (Barlow \& Alberte 1985) and $0.25{\mathrm{pg} \mathrm{C} \mathrm{\mu m}^{3}}^{3}$ (Verity et al. 1992), respectively. Picoplankton biovolume was calculated as the product between abundance and average cell volume $\left(3.9 \mathrm{\mu m}^{3}\right)$. The cell volume was calculated from the equivalent spherical diameter, as measured by the flow cytometer (and calibrated with beads and cells) and assuming that the particle is spherical.

Primary production and photosynthesis-irradiance $(\boldsymbol{P}-\boldsymbol{I})$ curve parameters. Primary production and $P-I$ curves of the $<2 \mu \mathrm{m}$ fraction were determined 3 times (at Days 1, 13 and 22) in mesocosm units receiving 25 and $100 \%$ ambient light, with and without nutrient amendment. Due to logistical constraints, these mea- 
surements were not determined in mesocosm units receiving 10 and $50 \%$ ambient light. The incident irradiance was measured daily through vertical casts with a Seabird CTD probe fitted with a PAR sensor. Twelve $125 \mathrm{ml}$ polycarbonate Nalgene bottles were dispensed each with $120 \mathrm{ml}$ of water from the mesocosm units. One $\mathrm{ml}$ of ${ }^{14} \mathrm{C}$ solution (10 to $20 \mu \mathrm{Ci}$ ) was added to each bottle. Duplicate bottles were suspended at different depths inside the mesocosm units to achieve 13, 21, 47, 68 and $100 \%$ (surface) ambient light level of the mesocosms. Duplicate dark bottles were also suspended inside the mesocosm units. The bottles were incubated for $3 \mathrm{~h}$ in situ, and immediately wrapped in dark plastic bags and brought back to the ship for further processing. A subsample of $20 \mathrm{ml}$ from each bottle was then fractionated using a polycarbonate $2 \mu \mathrm{m}$ pore size filter. The filtrate was then directly filtered through $0.45 \mu \mathrm{m}$ Millipore filters, and filters were fumed over concentrated $\mathrm{HCl}$ to remove traces of inorganic $\mathrm{C}$. Radioactivity on the filters was measured with a liquid scintillation counter with correction for quenching. All materials were acid-cleaned prior to use. Primary production or carbon uptake of samples incubated at $100 \%$ ambient light in hourly rates were converted to daily rates by multiplying by 14.9 daylight hours. $P-I$ curves were fitted to the hyperbolic tangent model (Jassby \& Platt 1976):

$$
P=P_{\max } \tanh \left(\alpha I / P_{\max }\right)-R
$$

where $P_{\max }$ is the maximum photosynthetic rate, $I$ is the irradiance, $\alpha$ is the slope of the curve at low light levels (photosynthetic efficiency), and $R$ is the respiration rate. The light intensity needed to saturate photosynthesis was calculated as $P_{\max } / \alpha$. Curve fits were completed using the non-linear fitting routine of the
SYSTAT statistical package. The amount of variance explained by the model varied between 57 and $93 \%$.

Microzooplankton grazing on picophytoplankton using fluorescently labeled analogs. Overall grazing rates on picophytoplankton in response to nutrient and light manipulations were estimated by following the disappearance rate of fluorescently labeled Chlorella cells with time in water samples from mesocosm bags receiving 25 and $100 \%$ ambient light, with and without nutrient amendment. The procedure used, derived from Sherr \& Sherr (1993) and involved (1) the preparation of a fluorescently labeled Chlorella, by staining heat-killed cultured Chlorella with a yellow green fluorescing dye, DTAF-5-(4'6-dichlorotriazin-2yl) aminofluoresce, and (2) the examination of the time course of fluorescent cell loss. The experiment was done twice only (at Days 5 and 10) due to logistical constraints, using duplicate bottles per mesocosm, and by duplicate subsampling per bottle. A volume of 21 of sample water was gently poured into duplicate Nalgene polycarbonate bottles and an additional duplicate of $0.2 \mu \mathrm{m}$ filtered water of the same sample water was prepared to control for disappearance of the fluorescent tracers by factors other than grazing (e.g. possible losses due to sticking of analogs to bottles). The bottles were incubated on deck in a tank with a flowthrough of surface seawater, and left undisturbed for at least 30 min to allow recovery of the microbial assemblage from handling shock. The fluorescent tracer solution was briefly sonicated for 2 several second bursts, and uniformly mixed with a vortex mixer. A subsample (1000 Chlorella cells $\mathrm{ml}^{-1}$ final conc.) was added to each bottle and quickly but gently mixed into the sample to create a uniform suspension. At selected time intervals $(0,24 \mathrm{~h})$, duplicate $2 \mathrm{ml}$ subsamples
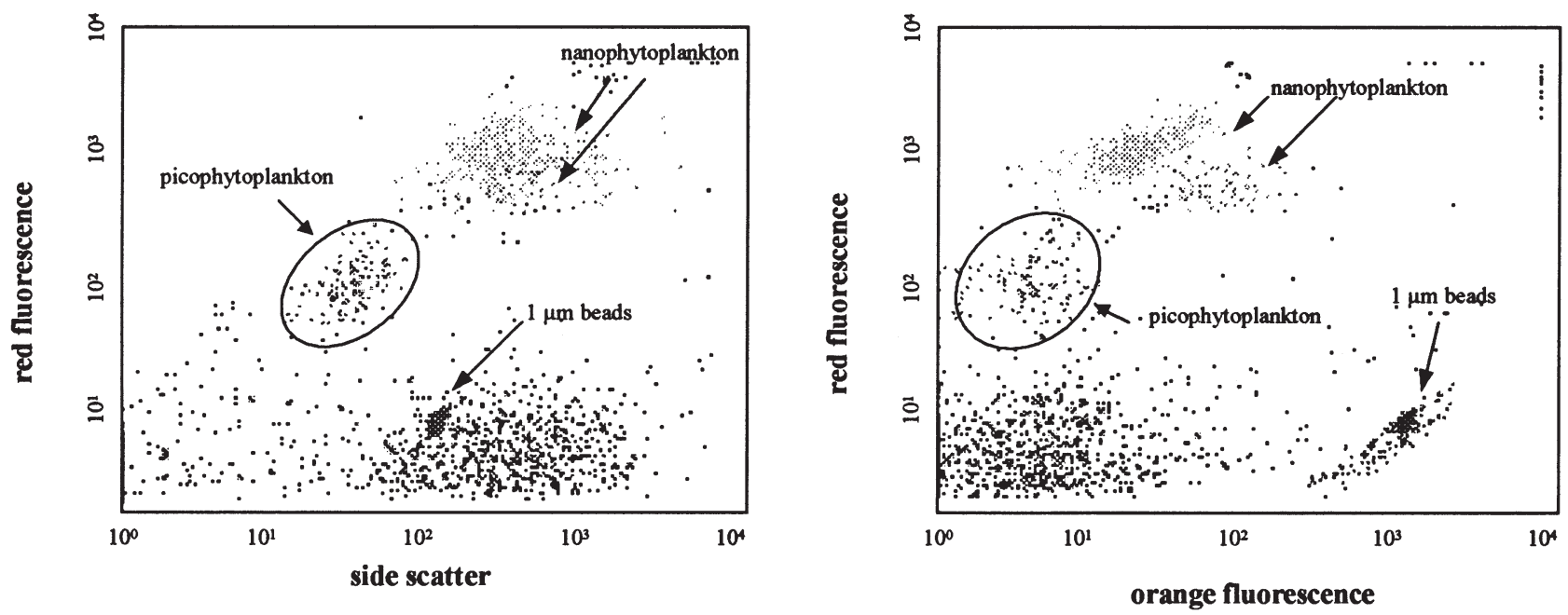

Fig. 2. Representave cytogram showing the eukaryotic picophytoplankton population studied 
were withdrawn from each bag and immediately preserved (with glutaraldehyde to $1 \%$ final conc.) in individual containers. The samples were quickly frozen in liquid nitrogen and stored at $-80^{\circ} \mathrm{C}$ until further analysis (counting of Chlorella cells) using the flow cytometer. The stained Chlorella cells were counted using the green and red fluorescence characteristics of the cells with a FACSCALIBUR flow cytometer.

\section{RESULTS}

The fluorescence signals obtained indicated that the picophytoplankton fraction in Johnson's Cove was composed of eukaryotic cells, and there was no evidence of the presence of prokaryotic picophytoplankton (Fig. 2). The stations occupied in the Bransfield area generally showed a subsurface maximum of picophytoplankton cells (Fig. 3), also eukaryotic, with a broad (range of 25-fold) abundance, with the highest abundance found in the Gerlache Strait and in some sites in the Bransfield area (Fig. 1).

The picophytoplankton contributed significantly to phytoplankton chlorophyll biomass in subsurface waters at Stns S2, S8 and S12 (Fig. 3). The abundance of picophytoplankton was positively, albeit weakly, correlated with water temperature $(\mathrm{r}=0.27, \mathrm{p}<0.05)$. Light extinction coefficients ranged from 0.05 to $0.38 \mathrm{~m}^{-1}$ with no clear pattern among the stations, and the mixed layer depth ranged from 12 to $92 \mathrm{~m}$. Picophytoplankton abundance was negatively correlated with the upper mixed layer depth $(\mathrm{r}=-0.60, \mathrm{p}=$ 0.05 , Fig. 4), which was negatively correlated with the mean light level for phytoplankton photosynthesis $(\mathrm{r}=$ $-0.88, \mathrm{p}<0.05, \log$ mean irradiance vs depth of the mixed layer). The mean light level for phytoplankton photosynthesis ranged from $\sim 0 \%$ of surface irradiance at the deepest mixed layers examined to $56 \%$ at the shallower mixed layers examined.

Ammonium concentrations during Phase I of the experiment were on average about 10 -fold higher than the initial values in mesocosms receiving nutrient amendment (Table 1). In nutrient-amended mesocosms receiving 50 and $100 \%$ ambient light, the discontinuance of nutrient-amendment after Day 11 coincided with the de- cline of ammonium concentrations until Day 16, from 11.5 to 9.2 and 7.7 to $3.6 \mu \mathrm{M}$ in mesocosms receiving 50 and $100 \%$ ambient light, respectively. These declines also coincided with the decline in picophytoplankton abundance in these units (Fig. 5).

Results of the experimental manipulation of light and nutrient availability showed that the abundance of picophytoplankton varied with time and with treatment (Fig. 5). Relative to the control (unamended mesocosm exposed to $100 \%$ ambient light), there was no effect of nutrient amendment in mesocosms receiving reduced light level (at 10 and $25 \%$ ambient light), while at higher light levels (mesocosms exposed to 50 and $100 \%$ ambient light), picophytoplankton abundance was almost double that in nutrient amended mesocosms during the first $16 \mathrm{~d}$ of the experiment (Fig. 5). The abundance of picophytoplankton increased when the unamended mesocosm exposed to full light was amended with ammonium at Day 16, and the abundance increased gradually when the mesocosm shaded to $25 \%$ ambient light was exposed to the

Table 1. Concentrations of ammonium, phosphate, and nitrate $(\mu \mathrm{M}$, mean $\pm \mathrm{SE})$ in the different mesocosm units. Phase I: the period of initial experimental conditions (the first $16 \mathrm{~d}$ ); Phase II the period where changes in treatments were made (mesocosms receiving $25 \%$ ambient light were exposed to full light, and ammonium additions were initiated to mesocosms previously receiving full ambient light). Initial nutrient concentrations (before any experimental treatments were initiated) are also shown

\begin{tabular}{|c|c|c|c|}
\hline & Initial & Phase I & Phase II \\
\hline \multicolumn{4}{|l|}{ Ammonium } \\
\hline $10 \%$ light & 0.60 & $0.61(0.09)$ & $0.90(0.06)$ \\
\hline $10 \%$ light + nutrients & 0.60 & $6.60(1.09)$ & $9.33(0.22)$ \\
\hline $25 \%$ light & 0.60 & $0.54(0.09)$ & $0.50(0.00)$ \\
\hline $25 \%$ light + nutrients & 0.60 & $5.34(0.95)$ & $6.38(0.54)$ \\
\hline $50 \%$ light & 0.60 & $0.49(0.07)$ & $0.50(0.05)$ \\
\hline $50 \%$ light + nutrients & 0.60 & $7.68(1.11)$ & $6.88(0.40)$ \\
\hline $100 \%$ light & 0.60 & $0.57(0.07)$ & $4.83(0.66)$ \\
\hline $100 \%$ light + nutrients & 0.60 & $4.77(0.72)$ & $6.46(0.71)$ \\
\hline \multicolumn{4}{|l|}{ Phosphate } \\
\hline $10 \%$ light & 1.62 & $1.79(0.06)$ & $1.81(0.07)$ \\
\hline $10 \%$ light + nutrients & 1.62 & $3.57(0.25)$ & $3.87(0.12)$ \\
\hline $25 \%$ light & 1.62 & $1.77(0.06)$ & $1.52(0.08)$ \\
\hline $25 \%$ light + nutrients & 1.62 & $3.03(0.20)$ & $3.06(0.15)$ \\
\hline $50 \%$ light & 1.62 & $1.64(0.07)$ & $1.25(0.04)$ \\
\hline $50 \%$ light + nutrients & 1.62 & $3.79(0.22)$ & $3.08(0.17)$ \\
\hline $100 \%$ light & 1.62 & $1.70(0.07)$ & $1.55(0.06)$ \\
\hline $100 \%$ light + nutrients & 1.62 & $3.19(0.20)$ & $3.27(0.16)$ \\
\hline \multicolumn{4}{|l|}{ Nitrate } \\
\hline $10 \%$ light & 27.48 & $25.76(0.67)$ & $28.96(0.85)$ \\
\hline $10 \%$ light + nutrients & 27.48 & $28.35(0.45)$ & $28.79(0.48)$ \\
\hline $25 \%$ light & 27.48 & $25.71(0.69)$ & $24.60(1.51)$ \\
\hline $25 \%$ light + nutrients & 27.48 & $26.95(0.73)$ & $28.14(0.84)$ \\
\hline $50 \%$ light & 27.48 & $23.78(0.79)$ & $17.91(0.75)$ \\
\hline $50 \%$ light + nutrients & 27.48 & $26.97 \quad(0.72)$ & $26.72(0.92)$ \\
\hline $100 \%$ light & 27.48 & $27.78(0.72)$ & $27.09(1.00)$ \\
\hline $100 \%$ light + nutrients & 27.48 & $27.75(0.54)$ & 22.19 \\
\hline
\end{tabular}




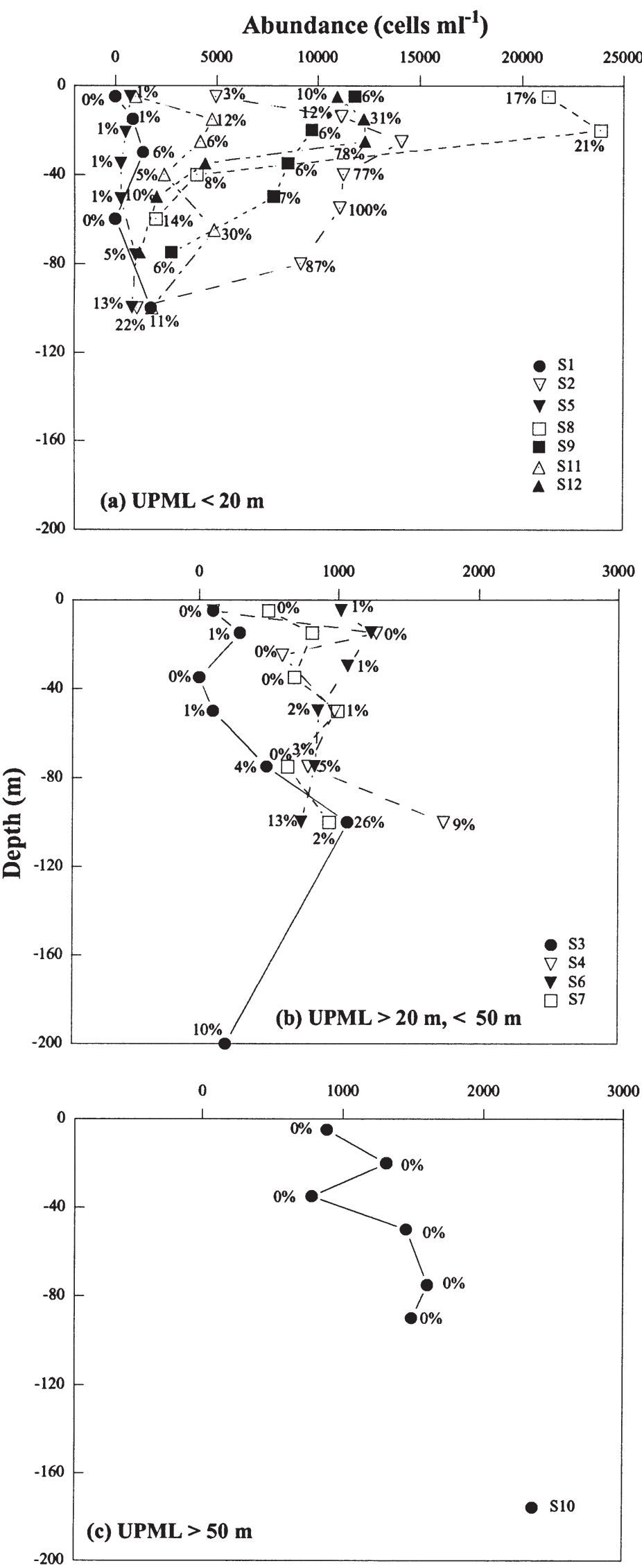

full ambient light at Day 16 (Fig. 5). The mean relative abundance of picophytoplankton increased in a hyperbolic manner with increased ambient irradiance during the first $16 \mathrm{~d}$ of the experiment (Fig. 6), with the highest mean relative abundance attained at the nutrient amended $50 \%$ irradiance mesocosm.

The average primary and specific primary production of picophytoplankton in nutrient-amended andunamended mesocosms exposed to full light was higher than the mesocosms shaded to $25 \%$ ambient light (Table 2). The average primary and specific primary production of picophytoplankton in the nutrientamended mesocosm exposed to full light was much higher (>20-fold) than those in the unamended mesocosm, whereas in the mesocosms shaded to $25 \%$ ambient light, the difference between the production in amended and unamended mesocosms was modest (Table 2).

The large response in primary production of the picoplankton was further assessed through the examination of the $P-I$ curves. At the start of the experiment, results of the $P-I$ curve experiments showed similar photosynthetic efficiencies of picophytoplankton between unamended and amended mesocosms shaded to $25 \%$ ambient light. These photosynthetic efficiencies were, however, lower than those for picophytoplankton exposed to full ambient light, particularly in the amended mesocosm (Table 3, Fig. 7). This pattern was more pronounced during the middle part of the experiment when the picophytoplankton in the amended mesocosm exposed to full light showed very high (50-fold greater) maximum photosynthetic rates along with a very high (>10-fold higher) photosynthetic efficiency (Table 3, Fig. 7).

Grazing rates on fluorescently labeled Chlorella cells showed similar rates across the mesocosm units during the early part of the experiment. During the middle part of the experiment, however, specific grazing rates were higher in mesocosms receiving $25 \%$ ambient light, particularly in the unamended unit, compared to mesocosms exposed to full ambient light (Fig. 8).

Particulate matter sedimentation rates during the first phase of the experiment ranged, on average, $0.53 \pm 0.12$ to $14.26 \pm 7.32 \mathrm{mg} \mathrm{chl} \mathrm{m}^{-2} \mathrm{~d}^{-1}$, with the lowest values observed in the mesocosm receiving only $10 \%$ ambient light without nutrient amendment, and the highest values observed in the mesocosm receiving full ambient light and nutrient amendment.

Fig. 3. Vertical profiles of abundance of picophytoplankton at the different stations grouped according to the depth of the upper mixed layer (UPML), namely (a) $<20 \mathrm{~m}$, (b) $>20 \mathrm{~m}$, $<50 \mathrm{~m}$, and (c) $>50 \mathrm{~m}$. Percentages indicated are the percent contribution of picophytoplankton to total phytoplankton chlorophyll biomass 


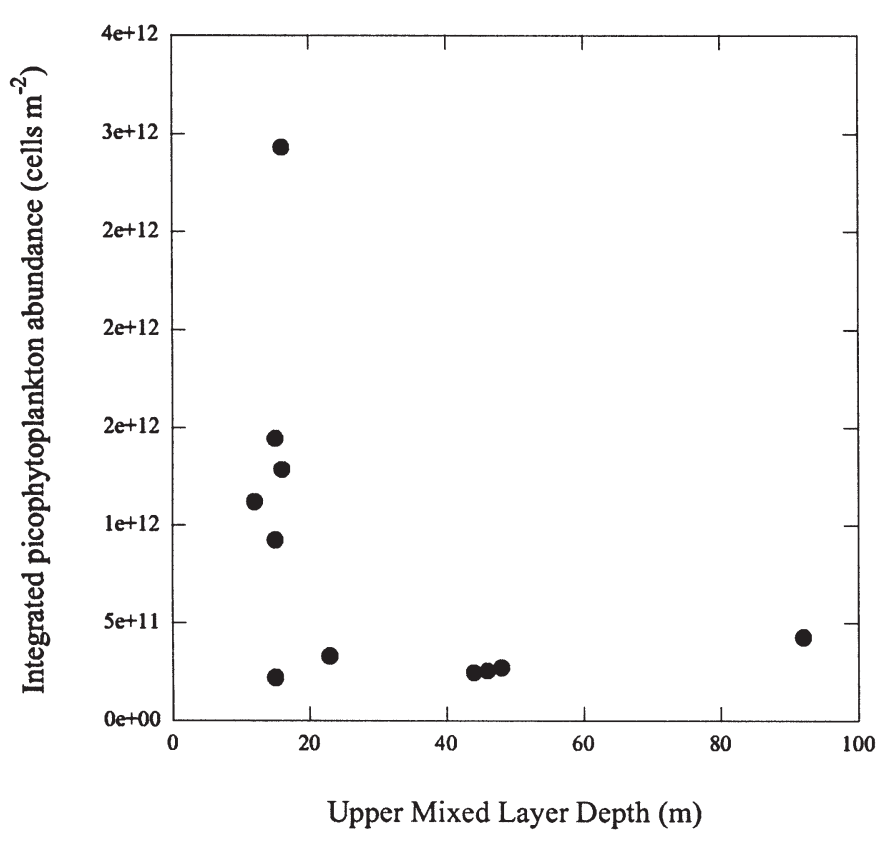

Fig. 4. Plot of the abundance of picophytoplankton and the depth of the upper mixed layer at the different stations

\section{DISCUSSION}

The results show that picophytoplankton dominated by picoeukaryotes can develop an important biomass in Antarctic waters, contributing almost $100 \%$ of the autotrophic biomass in subsurface Bransfield waters. The contribution of the picophytoplankton fraction to total primary production (35 to $75 \%$ ) and biomass (on average, $17 \%$ ) was also high in the waters of Johnson Cove. The picoeukaryote concentrations found in the different stations in the Bransfield Strait were quite variable, consistent with previous results (Weber \& ElSayed 1987) with lowest concentrations south of King George Island and higher concentrations occurring in the Bransfield and Gerlache straits. The highest picophytoplankton biomass found in the Antarctic stations surveyed here was within the upper range reported elsewhere in the ocean (Agawin et al. 2000). The lowest picophytoplankton integrated abundance is within the range reported in a site off the Kerguelen Islands (Fiala et al. 1998), while the highest picophytoplankton surface abundance exceeded those reported by Weber \& El-Sayed (1987) in Antarctic sites similar to those investigated here. These results support earlier contentions (Fiala et al. 1998) that picoplankton may have an important contribution to the autotrophic biomass in Antarctic waters.

The variability of picophytoplankton abundance in the area was associated with light availability, as evidenced by the negative correlation between the inte- grated picophytoplankton abundance and depth of the upper mixed layer. Picophytoplankton biomass remains low when the depth of mixing exceeds $20 \mathrm{~m}$, whereas high biomass may develop at shallower mixing depths. Hence, a mixed layer shallower than about $20 \mathrm{~m}$, corresponding to a mean irradiance of about $33 \%$ of surface irradiance, is a condition necessary but not sufficient to support high picophytoplankton biomass. This critical percent irradiance is comparable to the half saturation irradiance observed in the meso-

Table 2. Primary $\left(\mathrm{mg} \mathrm{C} \mathrm{m}^{-3} \mathrm{~d}^{-1}\right)$ and specific $\left(\mathrm{mg} \mathrm{C} \mathrm{mg} \mathrm{C}^{-1} \mathrm{~d}^{-1}\right)$ primary production (mean $\pm \mathrm{SE}$ ) during the mesocosm experiments. Phase I: the period of initial experimental conditions, Phase II: the period where changes in treatments were made (mesocosms receiving $25 \%$ ambient light were exposed to full light, and ammonium additions were initiated to mesocosms previously receiving full ambient light)

\begin{tabular}{|c|c|c|}
\hline & Phase I & Phase II \\
\hline \multicolumn{3}{|l|}{ Primary production } \\
\hline $25 \%$ light & $14.3(1.1)$ & $11.4(1.5)$ \\
\hline $25 \%$ light + nutrients & $6.3(1.5)$ & $10.9(0.8)$ \\
\hline $100 \%$ light & $18.8(4.2)$ & $10.8(1.4)$ \\
\hline $100 \%$ light + nutrients & $202.7(236)$ & $211(121)$ \\
\hline \multicolumn{3}{|c|}{ Specific primary production } \\
\hline $25 \%$ light & $1.4(0.1)$ & $1.5(0.2)$ \\
\hline $25 \%$ light + nutrients & $1.1(0.2)$ & $1.4(0.1)$ \\
\hline $100 \%$ light & $3.3(0.9)$ & $1.2(0.1)$ \\
\hline $100 \%$ light + nutrients & $64.5(26.3)$ & $41.9(24)$ \\
\hline
\end{tabular}

Table 3. Photosynthetic-irradiance parameters estimated during the mesocosm experiments. ${ }^{*}$ Curve was not completely saturated with the light available during the experiment; in these cases, the maximum photsynthetic rate $\left(P_{\max }\right.$ $\left.\mathrm{mgC}(\mathrm{mg} \mathrm{chl})^{-1} \mathrm{~h}^{-1}\right)$ value indicated is a minimum estimate. $\alpha$ : photosynthetic efficiency (mgC $(\mathrm{mg} \mathrm{chl})^{-1} \mathrm{~h}^{-1} / \mu \mathrm{mol}$ photons $\mathrm{m}^{-2} \mathrm{~s}^{-1}$ ). $E_{\mathrm{k}}$ : light intensity ( $\mu \mathrm{mol}$ photons $\mathrm{m}^{-2} \mathrm{~s}^{-1}$ ) needed to saturate photosynthesis, calculated as $P_{\max } / \alpha$ (Kirk 1983)

\begin{tabular}{|c|c|c|c|}
\hline & Day 1 & Day 13 & Day 22 \\
\hline \multicolumn{4}{|l|}{$\boldsymbol{P}_{\max }$} \\
\hline $25 \%$ light & $>6.83^{*}$ & & 8.84 \\
\hline $25 \%$ light + nutrients & 4.55 & $>7.60^{*}$ & 6.54 \\
\hline $100 \%$ light & 9.66 & 12.21 & 8.24 \\
\hline $100 \%$ light + nutrients & 3.64 & 653.6 & $>202^{*}$ \\
\hline \multicolumn{4}{|l|}{$\alpha$} \\
\hline $25 \%$ light & 0.035 & & 0.062 \\
\hline $25 \%$ light + nutrients & 0.034 & 0.111 & 0.067 \\
\hline $100 \%$ light & 0.049 & 0.540 & 0.098 \\
\hline $100 \%$ light + nutrients & 0.164 & 5.410 & 3.160 \\
\hline \multicolumn{4}{|l|}{$E_{\mathrm{k}}$} \\
\hline $25 \%$ light & * & & 142.6 \\
\hline $25 \%$ light + nutrients & 132.0 & * & 97.6 \\
\hline $100 \%$ light & 194.7 & 22.6 & 83.4 \\
\hline $100 \%$ light + nutrients & 22.2 & 120.8 & ${ }^{*}$ \\
\hline
\end{tabular}



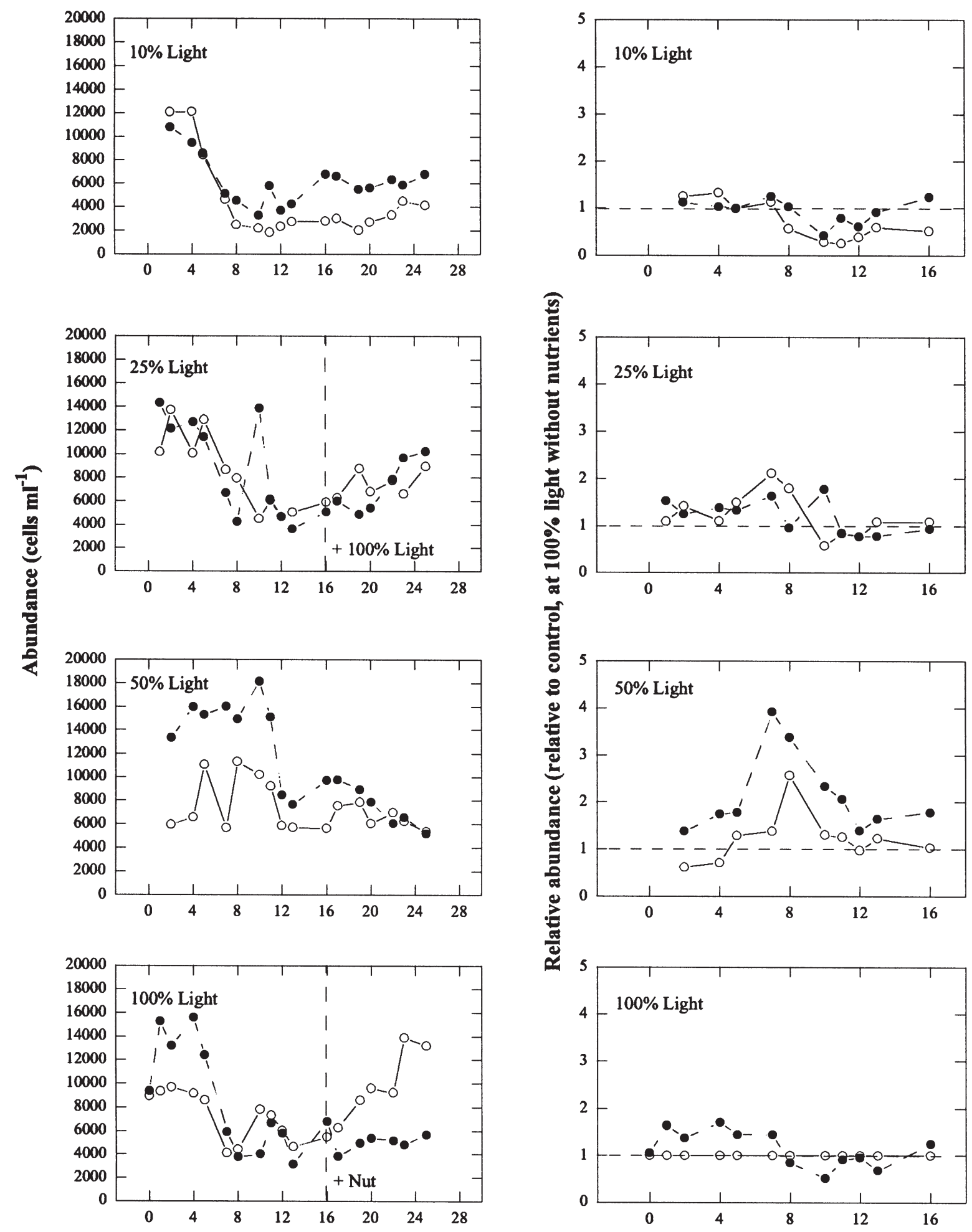

Time (days)

Time (days)

Fig. 5. (Left panels) Evolution of picophytoplankton abundance through time in the different mesocosm units (O); vertical dashed lines indicate the period when changes in treatments were made. (Right panels) Evolution of picophytoplankton relative abundance during the first $16 \mathrm{~d}$ of the experiment $(\mathrm{O})$; horizontal dashed lines indicate the control (at $100 \%$ light without nutrient amendment). (๑) Mesocosms receiving nutrient amendments 
cosm experiment, which is on average 23 and $52 \%$ of surface irradiance at mesocosms receiving full ambient light and shaded to $25 \%$ ambient light, respectively.

The apparent influence of light limitation on picophytoplankton primary production in the coastal Antarctic water studied may explain, together with the sensitivity to low temperature of marine cyanobacteria (Kuosa 1991), the dominance of the eukaryotic picoplankton and the absence of cyanobacterial species in Antarctic waters. Picocyanobacteria occur in very low concentrations in the Southern Ocean (Walker \& Marchant 1989, Kivi \& Kuosa 1994). The eukaryotic picophytoplankton and picocyanobacteria have distinctive spectral signatures which affect their photosynthetic performance success at low light conditions (Lewis et al. 1986). Culture experiments have shown that eukaryotic cells of similar size (e.g. Pavlova sp., Thalassiosira oceanica) outcompeted all cyanobacterial clones at low light and for a given chlorophyll concentration; the eukaryote is 3 to 7 times more efficient at absorbing and using light than the cyanobacterial strains (Lewis et al. 1986).

The responses to the experimental treatments on mesocosms provided further support for the importance of light in controlling picophytoplankton abundance, and provided additional evidence of an important role of nutrients. The importance of light availability was evident in the increased abundance of picophytoplank-

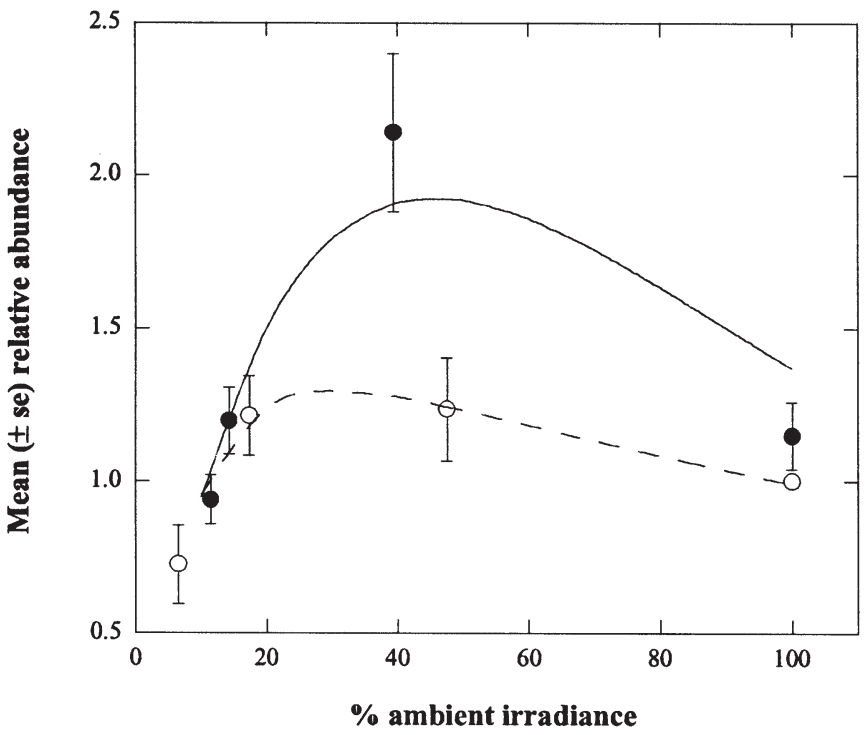

Fig. 6. Plot of mean $( \pm \mathrm{SE})$ picophytoplankton abundance relative to control-unamended mesocosm exposed to $100 \%$ light for the first $16 \mathrm{~d}$ of the experiment and actual \% of ambient irradiance, verified from daily water column measurements using a Seabird CTD fitted with a PAR sensor (O). (•) Mesocosms receiving nutrient amendments. Solid and dashed lines represent the underlying trends in nutrient and non-nutrient amended mesocosms, respectively ton with increased irradiance, and was further confirmed by the increased abundance when the mesocosms shaded to $25 \%$ ambient light were exposed to the full ambient light. The response of picophytoplank-
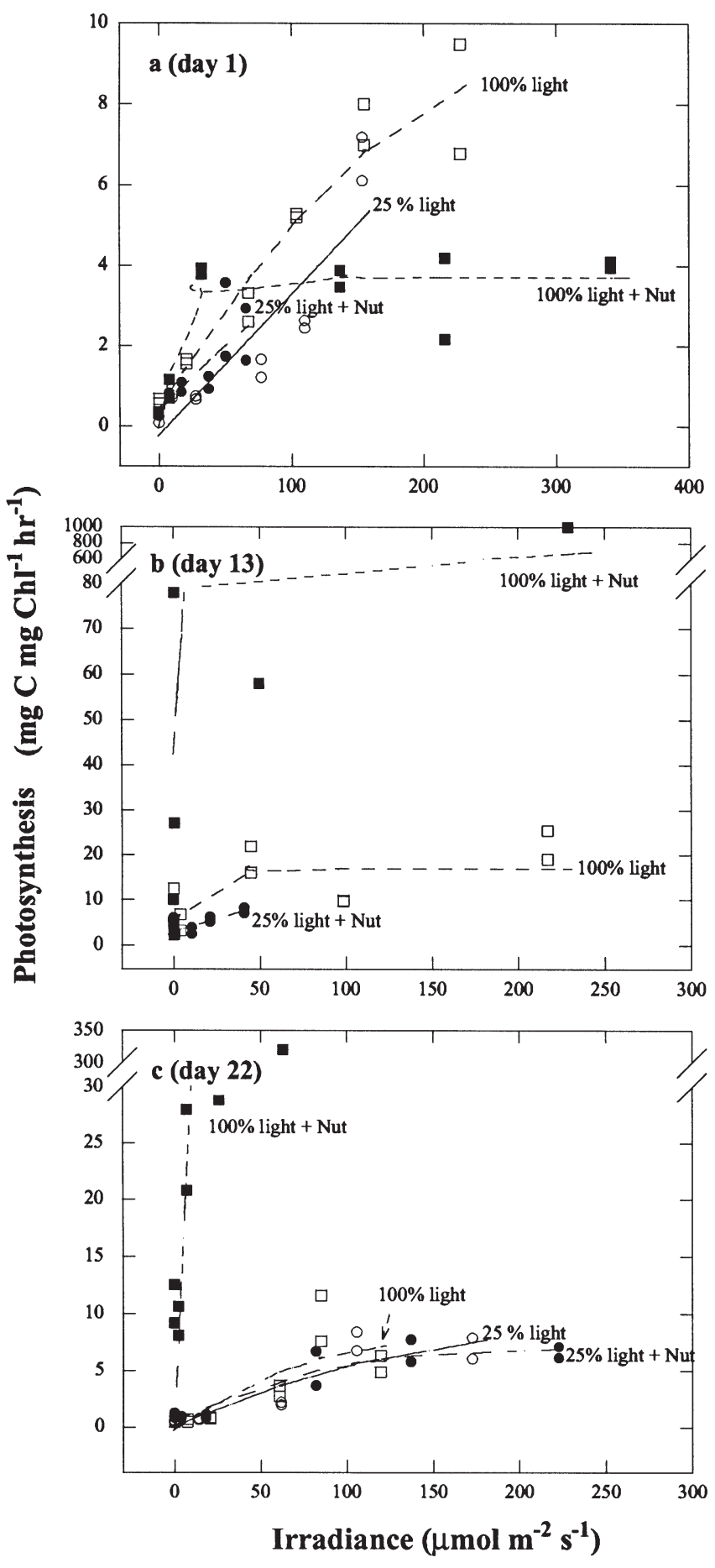

Fig. 7. Photosynthesis-irradiance curves of picophytoplankton in the different mesocosms studied at (a) Day 1, (b) Day 13 and (c) Day 22 of the experiment. (⿴) $100 \%$ light + nutrients,

() $100 \%$ light, (•) $25 \%$ light + nutrients, (0)25\% light 


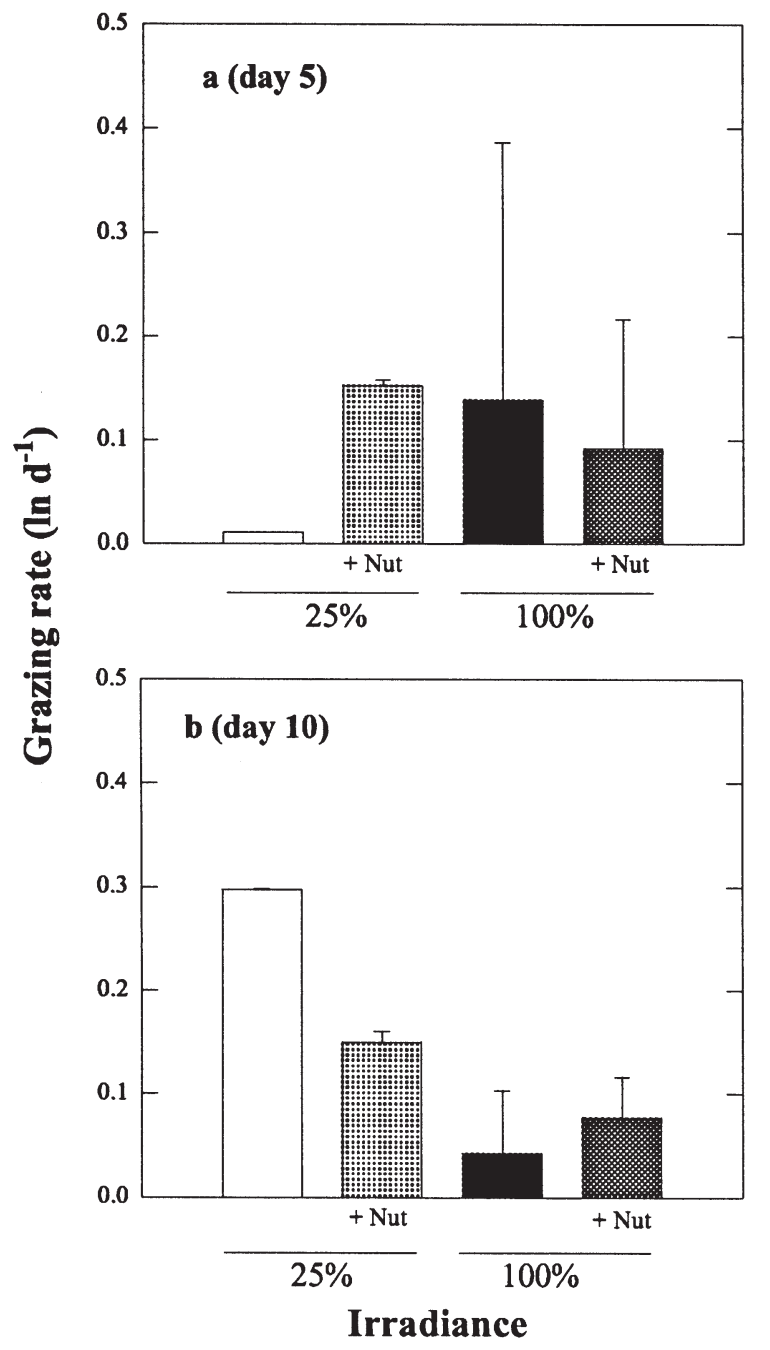

Fig. 8. Estimated grazing rates based on the disappearance of fluorescently labeled Chlorella cells during (a) Day 5 and (b) Day 10 of the experiment. Error bars denote $\pm \mathrm{SE}$

ton abundance to light availability was, however, non linear, with the abundance at full ambient irradiance being comparable, or lower, than that at $50 \%$ of the ambient irradiance. There was, in addition, an interaction between light availability and nutrient supply. This is evidenced by the increased picophytoplankton abundance during the early part of the experiment with increased nutrient availability (Table 3) in mesocosms exposed to 50 and $100 \%$ ambient light, and not in those shaded to 10 and $25 \%$ ambient light. This was further corroborated with the increased picophytoplankton abundance when the community previously grown at full ambient irradiance without nutrient amendments was supplied with ammonium during the second phase of the experiment.

The apparent dependence of picophytoplankton net population growth rate on light and nutrient (particu- larly ammonium) availability reflects their interaction in controlling picophytoplankton photosynthesis in the Antarctic coastal waters studied. The response of photosynthesis to irradiance $(P-I$ curves) showed an outstanding response to nutrient additions, with extremely high specific photosynthesis rates in the mesocosm exposed to full ambient light with increased nutrient availability. Except for mesocosms exposed to full ambient light with nutrient amendment, picophytoplankton specific photosynthetic rates were similar to those reported in the literature (Phlips \& Mitsui 1982, Joint 1986). When the community was grown at the full irradiance and supplied with nutrients, the specific photosynthesis rate by picophytoplankton was orders of magnitude higher, both in efficiency and $P_{\text {max }}$.

Calculation of the quantum yield $(0.105 \mathrm{~mol} \mathrm{C}$ per mol photon absorbed) and efficiency of light conversion $(21 \%)$ of picophytoplankton in the mesocosm exposed to full ambient light receiving nutrient amendment yielded estimates close to the upper limit (25\%) imposed by the physical and chemical constraints to photosynthesis (Kirk 1983). Such rates, close to the theoretical maximum possible, have not been observed for any other natural marine phytoplankton community in the past (Phlips \& Mitsui 1982), and provide ample evidence that nutrient (particularly ammonium) addition sets picophytoplankton in optimal conditions for photosynthesis in the iron-rich Antarctic coastal waters studied here. While there are possible sources of error in the calculations (e.g. the biovolume to chlorophyll conversions), these would result, at most, in a factor of 2 , which would still render these estimates uniquely high.

The abundance of picophytoplankton did not increase as expected from the very high photosynthetic activity achieved, suggesting important losses. The experiments conducted suggest grazing rates ( 0.02 to $0.3 \mathrm{~d}^{-1}$ ) to be modest relative to the inferred growth rates of the experimental picophytoplankton communities $\left(>1 \mathrm{~d}^{-1}\right)$. Hence, other losses, including mortality (e.g. due to UV stress) and sinking losses, may be important. Sinking losses of total particulate matter, quantified through the use of sediment traps deployed in the mesocosms, were relatively high in the mesocosm receiving the full ambient irradiance and nutrient inputs. These losses represented on average, about $83 \%$, of the picophytoplankton production in the mesocosm receiving the full ambient irradiance and nutrient inputs, although the actual share of picophytoplankton in the settling material was likely below this value. Sedimentation losses of picophytoplankton were considered negligible for pico-sized organisms (Pedros-Alio et al. 1989). Recent evidence, however, shows massive sedimentation of picoplankton em- 
bedded in large ( $>0.5 \mathrm{~mm}$ diameter) organic aggregates in high nutrient, low chlorophyll waters, where they were found within heterotrophic flagellates, within copepod fecal pellets, and within organic matrices, all of which were incorporated in organic aggregates (Waite et al. 2000). Via this mechanism, a large portion of picoplankton biomass may be transported below the euphotic zone.

In summary, the results found here indicated that Antarctic picophytoplankton abundance and primary production are extremely light limited, and that the primary production of picophytoplankton may be extraordinarily high when sufficient light is combined with nutrients, including ammonium. Yet, both the survey and experimental results demonstrate that large algal blooms are dominated by microphytoplankton, which led to the belief that the energy flow in Antarctic planktonic food webs was dominated by the linear food chain (i.e. diatoms-krill-whales, Guillard \& Kilham 1977). However, our results show that, despite their comparatively low biomass, the fast turnover of picophytoplankton allow them to contribute importantly to total planktonic primary production in Antarctic waters. The fact that the photosynthetic performance of picophytoplankton reached their physiological limits when enough light and nutrient supply were available indicates that there is no physiological barrier accounting for the comparatively modest biomass of picophytoplankton in Antarctic waters. Their biomass must therefore derive from high losses compared to the larger bloom-forming microphytoplankton. Examination of the nature and rates of the loss factors affecting picophytoplankton in Antarctic waters is, therefore, essential to understand their dynamics.

Acknowledgements. This research was part of the ESEPAC programme funded by the Spanish National Antarctic Programme (CICYT ANT97-0273). We thank Sofia Loureiro and all the participants of the ESEPAC 2000 for assistance in the laboratory, the personnel of the UGBO and the crew of the RV 'Hesperides' for assistance in deploying the mesocosm platform and the personnel of the Spanish Antarctic Base Juan Carlos I for support during the study. N.S.R.A. was supported by a fellowship from the Agencia Española de Cooperación Internacional.

\section{LITERATURE CITED}

Agawin NSR, Duarte CM, Agustí S (2000) Nutrient and temperature control of the contribution of picoplankton to phytoplankton biomass and production. Limnol Oceanogr 45:591-600

Agustí S, Duarte CM (2000) Experimental induction of a large phytoplankton bloom in Antarctic coastal waters. Mar Ecol Prog Ser 206:73-85

Barlow RG, Alberte RS (1985) Photosynthetic characteristics of phycoerythrin-containing marine Synechococcus sp. I.
Response to growth photon flux density. Mar Biol 86: 63-74

de Baar HJW, de Jong JTM, Bakker DCE, Loscher BM, Veth C, Bathmann U, Smetacek VS (1995) Importance of iron for plankton blooms and carbon dioxide drawndown in the Southern Ocean. Nature 373:412-415

Donald KM, Scanlan DJ, Carr NG, Mann NH, Joint I (1997) Comparative phosphorus nutrition of the marine cyanobacterium Synechococcus WH7803 and the marine diatom Thalassiosira weissflogii. J Plankton Res 19: 1793-1813

El-Sayed SZ (1984) Productivity of the Antarctic waters: a reappraisal. In: Holm-Hansen BL, Gilles R (eds) Marine phytoplankton and productivity. Springer Verlag, Berlin, p 19-34

Fiala M, Kopczynska EE, Jeandel C, Oriol L, Vetion G (1998) Seasonal and interannual variability of size-fractionated phytoplankton biomass and community structure at station Kerfix, off the Kerguelen Islands, Antarctica. J Plankton Res 20:1341-1356

Guillard RLL, Kilham P (1977) The ecology of marine planktonic diatoms. In: Werner D (ed) The biology of diatoms. Blackwell Scientific Publications, Oxford, p 372-469

Hansen K, Koroleff F (1999) Determination of nutrients. In: Grasshof K, Kremling K, Ehrhardt M (eds) Methods of seawater analysis. Wiley, Weiheim, p 159-228

Hewes CD, Sakshaug E, Reid FMH, Holm-Hansen O (1990) Microbial autotrophic and heterotrophic eukaryotes in Antarctic waters: relationships between biomass and chlorophyll, adenosine triphosphate and particulate organic carbon. Mar Ecol Prog Ser 63:27-35

Holm-Hansen O, El-Sayed SZ, Franceschini GA, Cuhel RL (1984) Primary production and the factors controlling phytoplankton growth in the southern ocean. In: HolmHansen BL, Gilles R (eds) Marine phytoplankton and productivity. Springer-Verlag, Berlin, p 11-50

Jassby AD, Platt T (1976) Mathematical formulation of the relationship between photosynthesis and light for phytoplankton. Limnol Oceanogr 21:540-547

Joint IR (1986) Physiological ecology of picoplankton in various oceanographic provinces. In: Platt T, Li WKW (eds) Photosynthetic picoplankton. Can Bull Fish Aquat Sci 214: 287-309

Kéruel R, Aminot A (1997) Fluorometric determination of ammonia in sea and estuarine waters by direct segmented flow analysis. Mar Chem 57:265-275

Kirk JT (1983) Light and photosynthesis in aquatic ecosystems. Cambridge University Press, Cambridge

Kivi K, Kuosa H (1994) Late winter microbial communities in the western Weddell Sea (Antarctica). Polar Biol 14: 389-399

Kuosa H (1991) Picoplanktonic algae in the northern Baltic Sea: seasonal dynamics and flagellate grazing. Mar Ecol Prog Ser 73:269-276

Lewis MR, Warnock RE, Platt T (1986) Photosynthetic response of marine picoplankton at low photon flux. In: Platt T, Li WKW (eds) Photosynthetic picoplankton. Can Bull Fish Aquat Sci 214:235-250

Mengesha S, Dehairs F, Fiala M, Elskens M, Goeyens L (1998) Seasonal variation of phytoplankton community structure and nitrogen uptake regime in the Indian Sector of the Southern Ocean. Polar Biol 20:259-272

Minas HJ, Minas M (1992) Net community production in 'High Nutrient-Low Chlorophyll' waters of the tropical and Antarctic Oceans: grazing vs iron hypothesis. Oceanol Acta 15:145-162

Mitchell BG, Holm-Hansen O (1991) Observations and mod- 
eling of the Antarctic phytoplankton crop in relation to mixing depth. Deep-Sea Res 38:981-1007

Morris I, Glover HE (1981) Physiology of photosynthesis by marine coccoid cyanobacteria - some ecological implications. Limnol Oceanogr 26:957-961

Parsons TR, Maita Y, Lalli CM (1984) A manual of chemical and biological methods for seawater analysis. Pergamon Press, Oxford

Pedros-Alio C, Mas J, Gasol JM, Guererro R (1989) Sinking speeds of free-living phototrophic bacteria determined with covered and uncovered sediment traps. J Plankton Res 11:887-905

Phlips EJ, Mitsui A (1982) Temperature preference and tolerance of aquatic photosynthetic microorganisms. In: Mitsui A, Black CC (eds) CRC handbook of biosolar resources, Vol 1. Basic principles, Part 2. CRC Press, Boca Raton, FL, p 335-361

Sakshaug E, Holm-Hansen O (1986) Photoadaptation in Antarctic phytoplankton: variations in growth rate, chemical composition and P versus I curves. J Plankton Res 8: 459-473

Editorial responsibility: William Li, Dartmouth, Nova Scotia, Canada
Sherr EB, Sherr BF (1993) Protistan grazing rates via uptake of fluorescently labeled prey. In: Kemp PF, Sherr BF, Sherr EB, Cole JJ (eds) Handbook of methods in aquatic microbial ecology. Lewis Publishers, Boca Raton, FL, p 695-701

Sommer U (1989) Maximal growth rates of Antarctic phytoplankton: only a weak dependence on cell size. Limnol Oceanogr 34:1109-1112

Verity PG, Robertson CY, Tronzo CR, Andrews MG, Nelson JR, Sieracki ME (1992) Relationships between cell volume and the carbon and nitrogen content of marine photosynthetic nanoplankton. Limnol Oceanogr 37:1434-1446

Waite AM, Safi KA, Hall JA, Nodder SD (2000) Mass sedimentation of picoplankton embedded in organic aggregates. Limnol Oceanogr 45:87-97

Walker TD, Marchant HJ (1989) The seasonal occurrence of chroococcoid cyanobacteria at an Antarctic coastal site. Polar Biol 9:193-196

Weber LH, El-Sayed SZ (1987) Contribution of the net-, nanoand picoplankton standing crop and primary productivity in the Southern Ocean. J Plankton Res 9:973-994

Submitted: January 3, 2002; Accepted: June 6, 2002

Proofs received from author(s): August 28, 2002 